\section{Study the effect of metformin in different pH of human blood medium using cyclic voltammetric technique}

\author{
Muhammed Mizher RADHI - Radiological Techniques Department, Health and Medical Technology \\ College-Baghdad, Middle Technical University (MTU), Iraq-mmradhi@yahoo.com \\ MoAaYAD Jassim AL-HAYANI - Radiological Techniques Department, Health and Medical Technology \\ College-Baghdad, Middle Technical University (MTU), Iraq \\ МонAmed Flayy TAREEF - Dean of Health and Medical Technology College-Baghdad, \\ Middle Technical University (MTU), Iraq
}

Érkezett: 2019. 03. 24. " Received: 24. 03. 2018. " https://doi.org/10.14382/epitoanyag-jsbcm.2019.16

\section{Abstract}

Metformin $\mathrm{HCl}$ is a drug to treatment of different diseases such as ovary, diabetes, and slimming. Present study includes the electrochemical analysis by cyclic blood medium at different $\mathrm{pH}$ to evaluate the oxidation - reduction current peaks of the metformin compound which appeared at +750 and $-750 \mathrm{mV}$ respectively in acidic blood medium, while the oxidation current peak of the metformin was disappeared in alkaline blood medium with present of reduction one, so metformin acts as antioxidant reagent in alkaline blood medium. The study device the patients whom have taken metformin tablets as a treatment for diabetic disease must take ascorbic acid with metformin tablet to avoid the oxidation stress.

Keywords: metformin, blood, cyclic voltammetry, different $\mathrm{pH}$, redox reaction

Kulcsszavak: metformin, vér, ciklikus voltametria, különbözô pH, redox reakció
Muhammed Mizher RADH

Professor, Department of Radiological Techniques, Health and Medical Technology College-Baghdad, Middle Technical University, Baghdad, Iraq. He received his PhD from University Putra of Malaysia (UPM) in 2010 in Electrochemistry, Nanotechnology. Research topics: conductivity of grafted polymer with nano-deposit and fabrication of sensors by nanomaterials to study drugs in blood medium by electrochemical analysis.

Moaayad Jassim AL-HAYANI Assistant professor, currently he is a lecture in the Department of Radiological Techniques, Health and Medical Technology College-Baghdad, Middle Technical University, Baghdad, Iraq He received M.S.D. physiology (cardiovascula physiology), Baghdad University, College of Veterinary medicine 1988 . His study focused on cardiovascular physiology. Mohamed Flayyh TAREEF Assistant Professor, Dean of the Health and Medical Technology College-Baghdad, Middle Technical University, Baghdad, Iraq. He received his PhD of Microbiology at Mustansiriah University, Baghdad, Iraq (2006). His study focused on microbiology (bacteriology).

\section{Introduction}

In the resent time scientists have chosen cyclic voltammetric technique to study medicines in blood medium [1-6].

Metformin $\mathrm{HCl}$ is known in chemical structure (1,1-dimethylbiguanide $\mathrm{HCl}$ ) as shown in Fig. 1. In the pharmacy market it is traded under the name of Glucophage and it is used as a treatment of type 2 diabetes, $[7,8]$ particularly for people who are overweight, has polycystic ovary syndrome, cardiovascular disease or cancer complications of diabetes $[9,10]$.<smiles>CN(C)C(=N)NC(=N)N</smiles>

Fig. 1 Structure of metformin

1. ábra A metformin kémiai felépitése

A new method was used to determine metformin of pharmaceuticals, serum and urine from volunteers after spiking with metformin. The results were examined by a standard addition method. The number of pharmacological supplements and blood serum or urine matrix did not affect the determination of metformin [11]. The modified electrode, multi-walled carbon nanotubes (CNTs) composites on glassy carbon electrode (GCE) showed an excellent response to the oxidativecurrent to determinemetformin compound.Inoptimal conditions, a good linear peak current with concentrations in a range of $0.5 \mu \mathrm{m}$ to $25 \mu \mathrm{m}$ and a detection unit of $0.12 \mu \mathrm{m}$, as well as good repetition, was shown. The modified GCE with CNTs were applied successfully to determine metformin in pharmaceutical samples with good accuracy [12]. In 56 cases of lactic acidity strongly associated with metformin, the $\mathrm{pH}$ of blood lactate had no predictive value. One can reasonably rule out the accumulation of metformin as a prognostic factor. Ultimately, the determinants of metformin associated lactic acidosis were appeared to be the nature and number of influencing factors. Significantly, most patients survived - although the average $\mathrm{pH}$ is not consistent with a positive outcome under other conditions [13]. A newly developed spectral method was used in the present research project to determine the drug metformin hydrochloride, through the complication of copper (II). Color products were measured at $530 \mathrm{~nm}$. The newly developed system for pharmaceutical analysis has been applied [14]. Metformin is an anti-diabetic drug that is widely used. HPLC is the most commonly used method for the analysis of metformin. Other methods include spectroscopy and potentiometric measurements. The drug is analyzed not only in a neat solution but also in pharmaceutical products alone and in combination with other drugs. Studies show that metformin can be successfully used to reduce the risk of cancer. However, a randomized trial is needed to see if the drug is useful among populations at risk for cancer. This review discusses the different methods used to analyze metformin and its potential role in carcinogen resistance [15].

In this work, metformin compound was studied by electrochemical analysis using cyclic voltammetric method in human blood medium at different $\mathrm{pH}$.

\section{Experimental methods}

\subsection{Cyclic voltammetric technique}

EZstat (Potentiostat / Glvanostat) series from NuVant Systems (manufactured in the USA) was used to carry out the measurements. The electrochemical analysis cell was connected to the potentio-state and monitored by the program that was 
installed on the computer to perform cyclic voltammetric measurement $(\mathrm{CV})$. Silver / silver chloride (Ag / $\mathrm{AgCl}$ in 3 $\mathrm{M} \mathrm{KCl}$ ) as reference electrode and platinum wire (diameter 1 $\mathrm{mm}$ ) was used as counter electrodes. The glass working carbon electrode (GCE) was used in this study after cleaning by polishing with alumina solution and treated using ultrasonic waterway for ten minutes for measurement performance.

\section{Materials}

Metformin $\mathrm{HCl}$ compound was received from Merk sante s.a.s (Germany). Blood samples from healthy humans obtained from the Baghdad Medical Center were collected for analysis after the serum was completely separated from the blood by an electronic centrifuge of type 8-1 (3,000 cycles / min). Deionized water was used to prepare water solutions. All serum blood samples were diluted with deionized water by 1: $9 \mathrm{ml}$ (serum: deionized water), $10 \mathrm{ml}$ of dilute serum was placed in a cyclic voltammetric cell.

\section{Results and discussion}

Previous research has addressed the effects of the use of metformin for the treatment of some diseases such as diabetes. In the current study we prove the effects of this treatment from an electrochemical study of the blood through the peaks of oxidation and reduction of metformin compound.

\subsection{Effect alkaline $\mathrm{pH}$ on metformin in blood medium}

According to the results of the $\mathrm{pH}$ studies of metformin in alkaline blood medium, Fig. 2 illustrated the cyclic voltammogram of the oxidation - reduction current peaks of metformin in the range of alkaline $\mathrm{pH}(8-12)$, it was found the oxidation current peak was disappeared in this $\mathrm{pH}$ and the reduction current peak was enhanced in higher $\mathrm{pH}$ (12).

Also, the oxidation - reduction current peaks of metformin at neutral blood medium $\mathrm{pH}$ (7) has appeared at 0.750 and $-0.5 \mathrm{~V}$ respectively and disappeared the oxidation one at alkaline blood medium $(\mathrm{pH}=12)$ as shown in Fig. 3. Thus, the metformin $\mathrm{HCl}$ compound act as anti-oxidative reagent in alkaline blood medium [16].

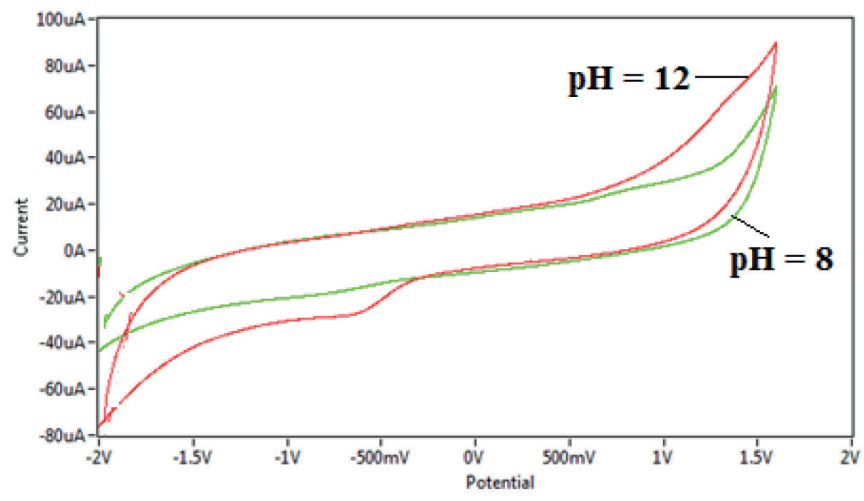

Fig. 2 Cyclic voltammogram of metformin in blood medium at different alkaline $\mathrm{pH}$ (8 and 12) using GCE and $\mathrm{Ag} / \mathrm{AgCl}$ as working and reference electrode at scan rate $0.1 \mathrm{~V} \mathrm{sec}^{-1}$

2. ábra 8 és 12 pH-jú vérben lévő metformin ciklikus voltammogramja, GCE és Ag/AgCl használatával mint munka- és referenciaelektróda, 0,1 $\mathrm{V} \mathrm{sec}{ }^{-1}$-es adatrögzitési sebesség mellett

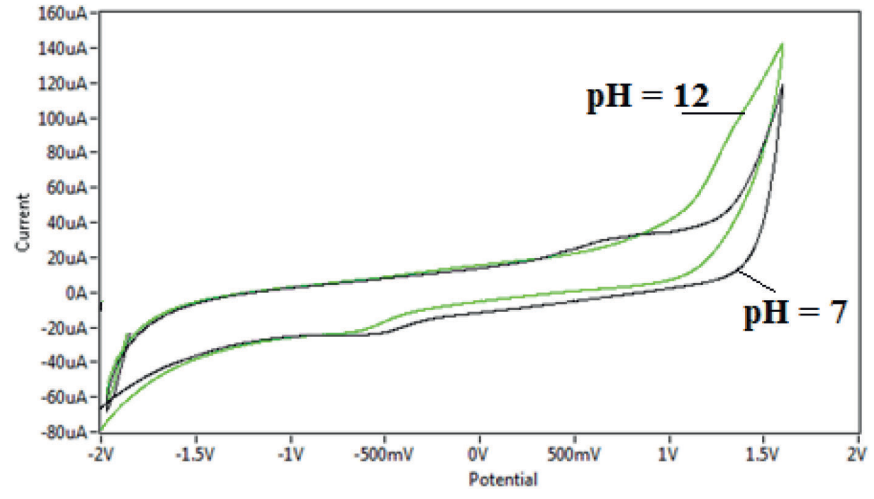

Fig. 3 Cyclic voltammogram of metformin in serum medium at different $p H$ ( 7 and 12) using GCE and Ag/AgCl as working and reference electrode at scan rate $0.1 \mathrm{~V} \mathrm{sec}{ }^{-1}$

3. ábra 7 és 12 pH-jú szérumban lévö metformin ciklikus voltammogramja, GCE és Ag/AgCl használatával mint munka- és referenciaelektróda, 0,1 $\mathrm{V} \mathrm{sec}^{-1}$-es adatrögzítési sebesség mellett

\subsection{Effect acidic $\mathrm{pH}$ on metformin in blood medium}

In the comparing study of metformin $\mathrm{HCl}$ compound between acidic and alkaline blood medium, it was found that oxidation - reduction current peaks of metformin have enhanced at acidic blood medium $\mathrm{pH}$ (3) as shown in Fig. 4, so the metformin in acidic blood medium acts as a catalyst for oxidation process [17].

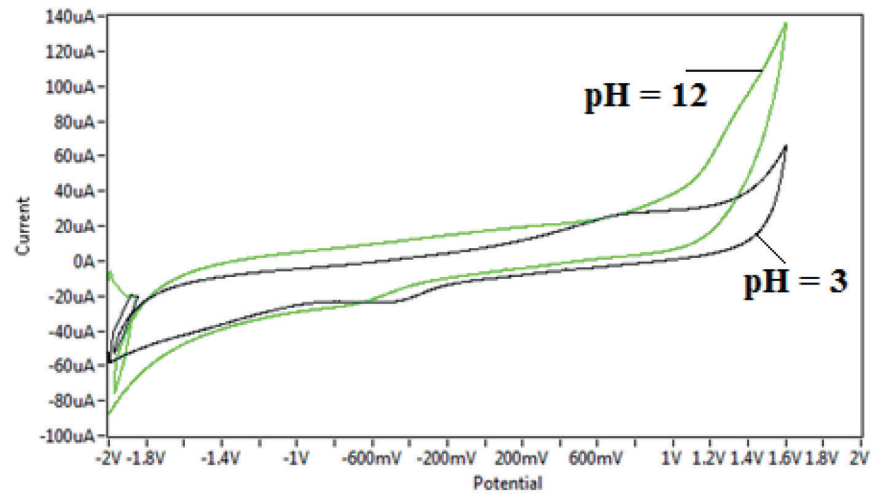

Fig. 4 Cyclic voltammogram of metformin in blood medium at different $\mathrm{pH}$ ( 3 and 12) using GCE and $\mathrm{Ag} / \mathrm{AgCl}$ as working and reference electrode at scan rate $0.1 \mathrm{~V} \mathrm{sec}^{-1}$

4. ábra 3 és 12 pH-jú vérben lévö metformin ciklikus voltammogramja, GCE és Ag/AgCl használatával mint munka- és referenciaelektróda, $0,1 \mathrm{~V} \mathrm{sec}^{-1}$-es adatrögzítési sebesség mellett

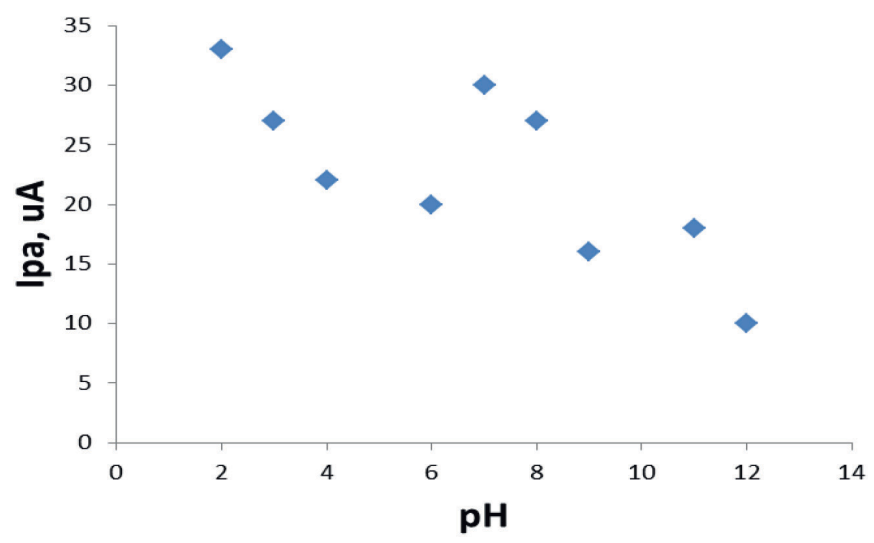

Fig. 5 Relationship between the oxidation current peak of metformin $\mathrm{HCl}$ and different $\mathrm{pH}$ of blood

5. ábra A metformin-HCl oxidációs csúcsa és a vér különbözö pH-ja közötti kapcsolat 


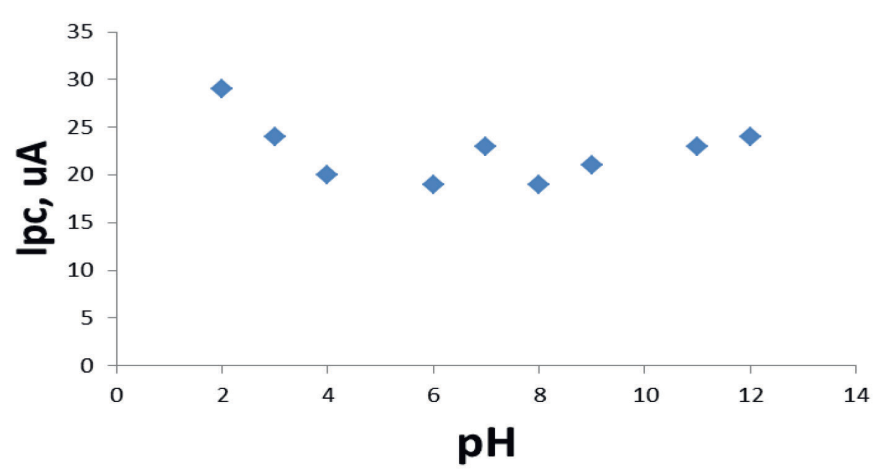

Fig. 6 Relationship between the reduction current peak of metformin $\mathrm{HCl}$ and different $\mathrm{pH}$ of blood

6. ábra A metformin-HCl redukciós csúcsa és a vér különbözö $p H$-ja közötti kapcsolat

It was found from the results of the oxidation - reduction current peaks of metformine in different $\mathrm{pH}$ (2-12) that reduction current peak was enhanced in alkaline blood medium with disappearing the oxidation peak as shown in Fig. 5 and 6.

\subsection{Effect of different medium on the redox current peaks of metformin}

Fig. 7 illustrates the cyclic voltammogram of metformin $\mathrm{HCl}$ in each of blood and serum (plasma) at alkaline $\mathrm{pH}$ (12) to find the difference between the two electrolytes, which indicated that the blood and its serum have the same properties in electrochemical analysis and the overlapping of the cyclic voltammogram [18].

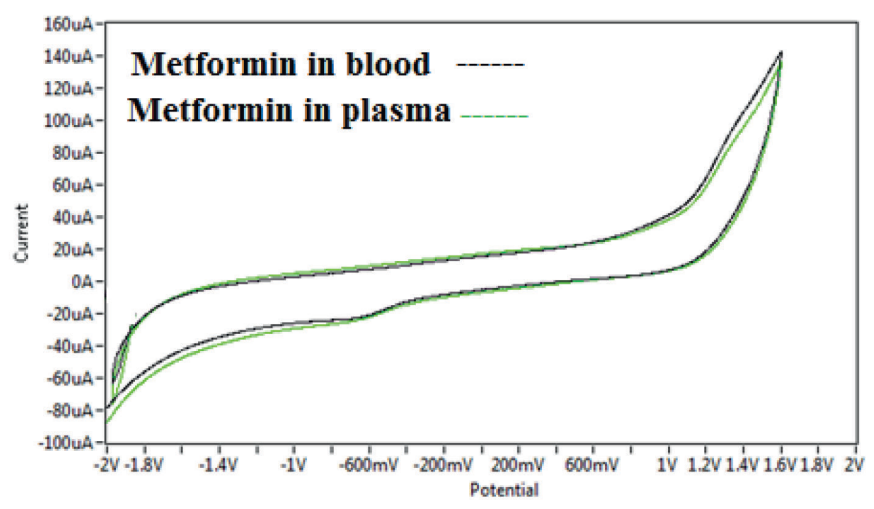

Fig. 7 Cyclic voltammogram of metformin in each of blood and plasma medium at alkaline $\mathrm{pH}$ (12) using GCE and $\mathrm{Ag} / \mathrm{AgCl}$ as working and reference electrode at scan rate $0.1 \mathrm{~V} \mathrm{sec}^{-1}$

7. ábra 12 pH-jú vérben és plazmában lévő metformin ciklikus voltammogramja, GCE és Ag/AgCl használatával mint munka-és referenciaelektróda, $0,1 \mathrm{~V}$ sec $^{-1}$-es szkennelési sebesség mellett

\section{Conclusions}

Based on the present research, it can be concluded that the treatment of metformin $\mathrm{HCl}$ for all medical use cases need to be taken carefully as results from the electrochemical analysis of this compound in different $\mathrm{pH}$ of serum medium. It was found that using metformin in acidic blood medium causes an oxidative stress by enhancing the oxidation current peak which indicated as oxidative medicine, while the metformin acts as anti-oxidative drug in alkaline blood medium by disappearing the oxidation current peak. Thus, an important advice to the users of this medicine is to take the complements as blood alkaline synthesis such as ascorbic acid to make the treatment safer.

\section{References}

[1] Muhammed Mizher Radhi, Maysara Samer Khalaf, Zainab Oun Ali, Voltammetric study of saffron in blood mediated by modified glassy carbon electrode (GCE) with carbon nanotube (CNT/GCE), Journal of Silicate Based and Composite Materials, 2018, Vol. 70, No. 3, 78-81, https://doi.org//10.14382/epitoanyag-jsbcm.2019.1

[2] Muhammed Mizher Radhi, Lamyaa Abd Alrahman Jawad, Emad Abbas Jaffar Al-Mulla, Thamer Aboud Al-Dabbagh, Saffron in KCl Mediated by Glassy Carbon Electrode Using Cyclic Voltammetry, Nano Biomed. Eng., 2018, Vol. 10, Iss. 2, 181-185. https://doi.org/10.5101/nbe.v10i2.p181-185.

[3] Muhammed Mizher Radhi, Zuhair Numan Hamed, Selda Sabah Ezzaldeen, Emad Abbas Jaffar Al-Mulla, Effect of Micro- and Nanoparticles of Ampicillin Trihydrate on Blood Medium: A Voltammetric Study, Nano Biomed. Eng., 2017, Vol. 9, Iss. 3, 185-190. https://doi.org/10.5101/nbe.v9i3.p185-190

[4] Muhammed Mizher Radhi, Emad A. Jaffar Al-Mulla, Use of a grafted polymer electrode to study mercury ions by cyclic voltammetry, Res Chem Intermed, vol.41, no.6, 1413-1420, 2015.

[5] Muhammed Mizher Radhi, Hanaa Naji Abdullah, Majid Sakhi Jabir Emad Abbas Jaffar Al-Mulla, Electrochemical Effect of Ascorbic Acid on Redox Current Peaks of $\mathrm{CoCl} 2$ in Blood Medium, Nano Biomed. Eng. 2017, Vol. 9, Iss. 2, 103-106. https://doi.org/10.5101/nbe.v9i2.p103-106.

[6] Muhammed Mizher R., Ali Abdulabbas Abdullah Albakry, Amani Mohammad Jassim, Sura Ali Alassady, Emad A. Jaffar Al-Mulla, Electrochemical Study of $\mathrm{Pb}$ (II) in Present of EachAscorbic Acid, Glucose, Urea and Uric Acid UsingBlood Medium as an Electrolyte, Nano Biomed Eng2016; 8(1): 9-15. https://doi.org/10.5101/nbe.v8i1.p9-15.

[7] Maruthur NM, Tseng E, Hutfless S, Wilson LM, Suarez-Cuervo C, Berger Z, Chu Y, Iyoha E, Segal JB, Bolen S. Diabetes Medications as Monotherapy or Metformin-Based Combination Therapy for Type 2 Diabetes: A Systematic Review and Meta-analysis. Annals of Internal Medicine., 2016, 164 (11): 740-51. https://doi.org/10.7326/M15-2650. Epub 2016 Apr 19

[8] Clinical Obesity (2nd ed.). Oxford: John Wiley \& Sons. 2008. p. 262

[9] Malek M, Aghili R, Emami Z, Khamseh ME, Risk of cancer in diabetes: the effect of metformin, ISRN Endocrinology. 2013: 636927. https://doi.org/10.1155/2013/636927. PMC 3800579. PMID 24224094.

[10] Type 2 diabetes and metformin. First choice for monotherapy: weak evidence of efficacy but well-known and acceptable adverse effects, Prescrire International. 23 (154): 269-72, 2014.

[11] Malik AlamgirMalik AlamgirAmir HayatAmir HayatAsghar Ali MajidanoAsghar Ali MajidanoMuhammad Yar KhuhawarMuhammad Yar Khuhawar, Spectrophotometric Determination of Metformin in Pharmaceutical Preparations, Serum and Urine using Benzoin as Derivatizing Reagent, J.Chem.Soc.Pak., Vol. 36, No. 2, 2014, 344.

[12] Mojtaba Hadi*, Haniyeh Poorgholi and Hossein Mostaanzadeh, Determination of Metformin at Metal-Organic Framework (Cu-BTC) Nanocrystals/Multi-walled Carbon Nanotubes Modified Glassy Carbon Electrode, S. Afr. J. Chem., 2016, 69, 132-139. https://doi.org/10.17159/0379-4350/2016/v69a16

[13] Kajbaf F, Lalau JD., The prognostic value of blood $\mathrm{pH}$ and lactate and metformin concentrations in severe metformin-associated lactic acidosis., BMC Pharmacol Toxicol. 2013, 12;14:22. https://doi.org/10.1186/2050-6511-14-22.

[14] Issam M. A. Shakir, Basim I. Al-abdli and Huda M. Nafea, Continuous Flow Injection Analysis (CFIA) of Metformin Hydrochloride using Microphotmeter Equipped with 530 and 550nm LED., Journal of AlNahrain University Vol.16 (4), December, 2013, pp.29-36 Science 29

[15] Wajiha Gul, Metformin: Methods of Analysis and Its Role in Lowering the Risk of Cancer, Journal of Bioequivalence \& Bioavailability, Gul, J Bioequiv Availab, Volume 8(6): 254-259 (2016). https://doi.org/10.4172/jbb.1000305

[16] Ali K. Attia, Waheed M. Salem and Mona A. Mohamed Voltammetric Assay of Metformin Hydrochloride Using Pyrogallol Modified Carbon Paste Electrode, Acta Chim. Slov. 2015, 62, 588-594. https://doi.org/10.17344/acsi.2014.950 
[17] Ambrish Singh, Eno. E. Ebenso, M. A. Quraishi, Theoretical and Electrochemical Studies of Metformin as Corrosion Inhibitor for Mild Steel in Hydrochloric Acid Solution, Int. J. Electrochem. Sci., 7 (2012) $4766-4779$.

[18] M.KhanaJ.H.Kuipera Christine Sieniaws kab J.B.Richardson, Differences in concentration of metal debris in blood, serum, and plasma samples of patients with metal-on-metal hip resurfacing arthroplasty, Journal of Orthopaedics, Volume 13, Issue 4, 2016, Pages 450-454. https://doi.org/10.1016/j.jor.2015.10.006 $\underline{\text { Ref.: }}$

Radhi, Muhammed Mizher - Al-Hayani, Moaayad Jassim - Tareef, Mohamed Flayyh: Study the effect of metformin in different $p H$ of human blood medium using cyclic voltammetric technique Építőanyag - Journal of Silicate Based and Composite Materials, Vol. 71, No. 3 (2019), 88-91. p.

https://doi.org/10.14382/epitoanyag-jsbcm.2019.16

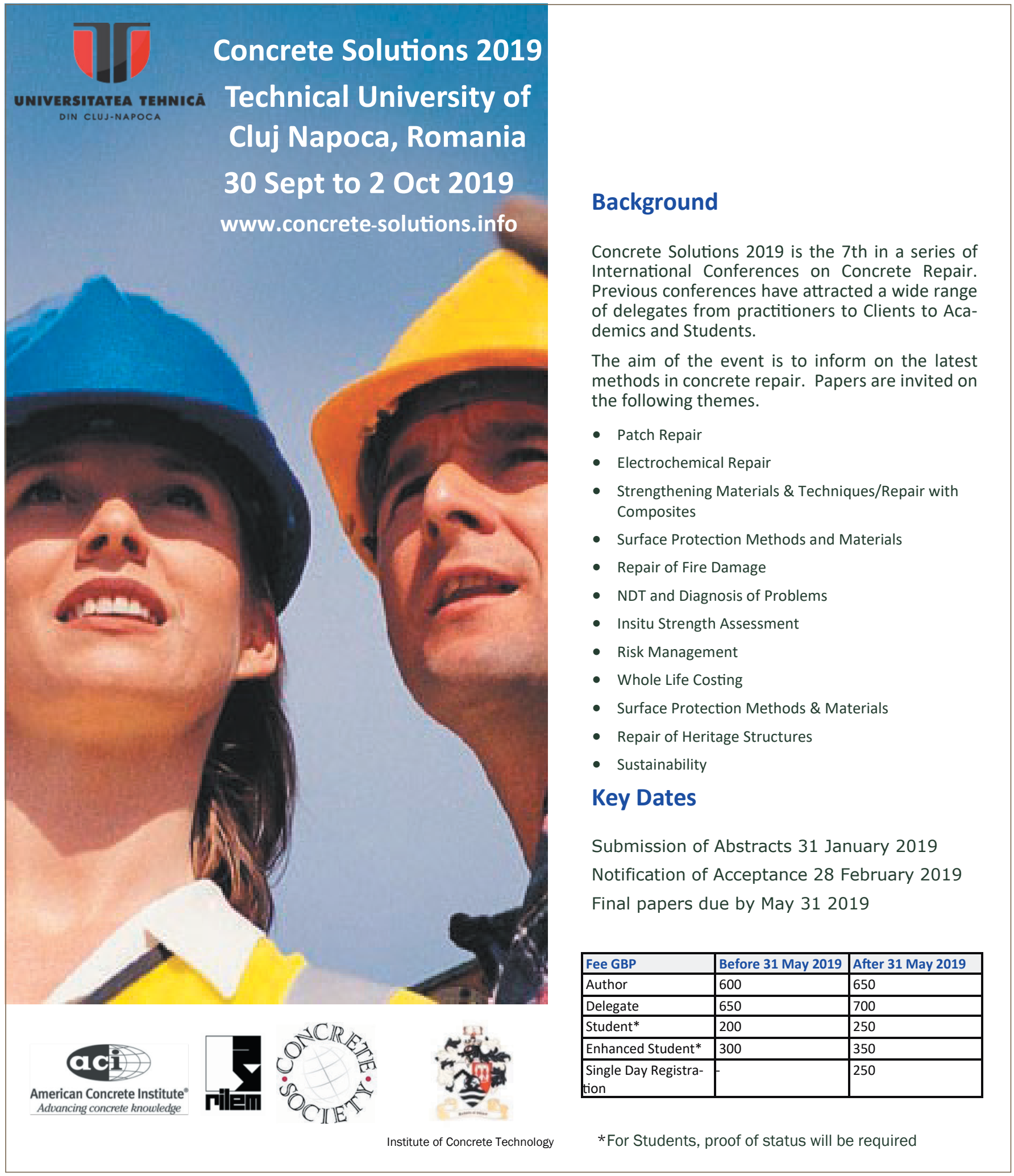

